\title{
Systematic review of outcomes of combined proximal stent grafting with distal bare stenting for management of aortic dissection
}

\author{
Ludovic Canaud, MD, PhD, Benjamin O. Patterson, BSc, George Peach, MRCS, \\ Robert Hinchliffe, MD, FRCS, Ian Loftus, MD, FRCS, and Matt M. Thompson, MD, FRCS
}

Objective: Available data on outcomes of combined proximal stent grafting with distal bare stenting for management of aortic dissection are limited. This is a systematic review of outcomes of this approach.

\begin{abstract}
Methods: Studies involving combined proximal stent grafting with distal bare stenting for management of aortic dissection were systematically searched and reviewed.
\end{abstract}

\begin{abstract}
Results: A total of 4 studies were included, with 108 patients treated for acute $(n=54)$ and chronic $(n=54)$ aortic dissection. Technical success rate was $95.3 \%$ (range, $84-100$ ). The 30-day mortality was $2.7 \%$ (range, $0 \%-5 \%$ ). Morbidity rate within 30 days was $51.8 \%$ (range, $0 \%-65 \%$ ) and included stroke (2.7\%), paraplegia $(2.7 \%)$, retrograde dissection $(1.8 \%)$, renal failure (14.8\%), severe cardiopulmonary complications $(5.5 \%)$, and bowel ischemia $(0.9 \%)$. Incidence of type I endoleak was $9.2 \%(10 / 108)$. During follow-up, 5 patient deaths $(4.6 \%)$ were related to aortic rupture or aortic repair. Reintervention rate was from $12.9 \%$. Two cases of delayed retrograde type A dissection (1.9\%) and 1 case of aortobronchial fistula $(0.9 \%)$ were reported. Most common delayed complication was thoracic stent-graft migration (4.7\%). Device failure rate was $9.2 \%$. Favorable aortic remodeling was observed: studies reporting midterm follow-up of the true lumen demonstrated high rates of false-lumen regression and true-lumen expansion. At 12 months, complete false-lumen thrombosis was observed at the thoracic level in $70.4 \%$ and at the abdominal level in $13.5 \%$.
\end{abstract}

Conclusions: Combined proximal stent grafting with distal bare stenting for management of aortic dissection appears to be a reasonable approach for type $\mathrm{B}$ aortic dissection, clearly improved true-lumen perfusion and diameter although failing to suppress false-lumen patency completely. Contemporary information on this approach is mainly provided by small series with a wide range of results. (J Thorac Cardiovasc Surg 2013;145:1431-8)

Acute dissection is the most common fatal aortic catastrophe, and the surgical treatment of Stanford type B acute aortic dissection remains a formidable challenge. The standard strategy for uncomplicated Stanford type B acute aortic dissection is medical management, with surgical intervention reserved for cases complicated by rupture, malperfusion, intractable pain, uncontrolled hypertension, and aneurysmal dilatation.

During the past decade, thoracic endovascular aortic repair (TEVAR) has been increasingly used to treat this condition when intervention has been necessary. The aim is to cover the entry tear to direct aortic flow preferentially into the true lumen. In one review, endovascular repair of acute complicated type B aortic dissection was associated with a lower 30-day mortality $(2.8 \%)$ than that of open repair, and TEVAR was therefore regarded as the surgical therapy

\footnotetext{
From the Department of Outcomes Research, St. George's Vascular Institute, London, United Kingdom.

L.C. is financially supported by the French Society For Vascular Surgery.

Disclosures: Authors have nothing to disclose with regard to commercial support.

Received for publication Nov 5, 2012; revisions received Feb 6, 2013; accepted for publication Feb 27, 2013; available ahead of print March 25, 2013.

Address for reprints: Ludovic Canaud, MD, PhD, St. George's Vascular Institute, Room 4.007, St. George's Healthcare NHS Trust, Blackshaw Rd, London SW17 0QT, UK (E-mail: ludoviccanaud@hotmail.com).

$0022-5223 / \$ 36.00$

Copyright $(2013$ by The American Association for Thoracic Surgery

http://dx.doi.org/10.1016/j.jtcvs.2013.02.060
}

of choice. ${ }^{1}$ Even if it is associated with a lower mortality than open surgery, however, stent grafting of complicated chronic type B aortic dissection remains controversial, despite thrombosing the false lumen adjacent to the stentgraft, because of concerns regarding durability.

Tsai and colleagues ${ }^{2}$ showed that the natural course of false-lumen partial thrombosis in type B aortic dissection has a worse prognosis than that of a completely patent false lumen. ${ }^{3}$ Complete exclusion of the false lumen, however, could improve the prognosis of this disease. To promote true-lumen expansion and false-lumen thrombosis, devices with bare metal stents that extend into the thoracoabdominal aorta have been used in an attempt to induce aortic remodeling. The ultimate aim of this technique is to prevent aortic aneurysmal evolution and rupture and to decrease the number of additional procedures required.

The aim of this study was to provide a systematic review of series that describe the outcomes of combined proximal stent grafting with distal bare stenting for the management of thoracic aortic dissection.

\section{MATERIALS AND METHODS \\ Search Strategy}

A literature search was undertaken to identify all published studies in the past 10 years reporting the combination of proximal stent grafting 


\section{Abbreviation and Acronym}

TEVAR $=$ thoracic endovascular aortic repair

with distal bare stents for management of aortic dissection. Candidate studies in English were sought through a computerized search of MEDLINE (National Library of Medicine, Bethesda, Md) databases for the period of 1950 to September 2012. Key words entered in this search were "thoracic aorta" or "bare stent" "dissection," "endovascular," and "PETTICOAT." Additionally, manual evaluation of the reference lists of the retrieved articles and reviews on this area subject was undertaken.

\section{Study Selection}

Studies were considered for inclusion on the basis of the following criteria: (1) reporting on combined proximal stent grafting with distal bare stenting for management of aortic dissection, including at least 5 patients treated with this method, and reporting on clinical outcome. Studies containing duplicate data were excluded, and the studies from the same authors with the most recent or the best-documented material were used for analysis.

\section{Data Extraction}

Data were extracted regarding demographics, comorbidity, case selection (proportion of acute and chronic dissections, proportion of patients with symptoms, operative details, technical success, and early and midterm outcomes (endoleak, retrograde dissection, aortic rupture, stroke, paraparesis or paraplegia, renal failure, bowel ischemia, severe cardiopulmonary complications, 30-day and midterm mortalities, freedom from reintervention).

Severe morbidity was defined as mortality related to aortic repair or any of following nonfatal adverse events occurring within the postoperative hospital period: central nervous system complication (stroke or spinal cord ischemia with permanent deficit), type I endoleak, retrograde type I dissection, acute renal failure (attested by the need to initiate hemodialysis for the first time), cardiac failure, pulmonary distress syndrome or severe lung infection, bowel ischemia, aortobronchial fistula, and unplanned return to surgery.

Perioperative severe morbidity was defined as severe morbidity occurring within the first 30 postoperative days. Midterm morbidity was defined as severe morbidity occurring after the first 30 postoperative days.

\section{RESULTS}

\section{Search Results}

Four studies were integrated after a literature search and the exclusion of duplicated publications ${ }^{3-6}$ (Table 1).

\section{Case Selection}

Patient demographic characteristics, presenting features, and comorbidities are shown in Tables 1 and 2. The mean age was 57.5 years, and $75.9 \%$ of the patients were male. The indication for endovascular repair (Table 3) was the presence of features of complicated aortic dissection (15 type A vs 93 type B; 54 acute vs 54 chronic). The most common comorbidities were hypertension $(87.9 \%)$, hyperlipidemia $(18 \%)$, renal failure $(15.6 \%)$, and cardiac disease $(12 \%)$.

The most commonly stated indication for intervention was malperfusion arising from branch vessel obstruction or true-lumen collapse $(76 / 108,70.3 \%)$. Other indications included refractory hypertension $(41 / 108,37.9 \%)$, refractory chest pain $(36 / 108,33.3 \%)$, rapid aortic enlargement (5 mm within 3 months) or transaortic diameter greater than $40 \mathrm{~mm}(35 / 108,32.4 \%)$, and periaortic effusion or hematoma $(10 / 108,9.2 \%)$. Acute and chronic dissections could not be separated for the purpose of analysis.

\section{Technical Success (Tables 4 and 5)}

The Cook Zenith dissection device (Cook Medical Inc, Bloomington, Ind) was the most common deployed graft $(96 / 108,88.8 \%)$. A median of 1.27 stent-grafts (range, $1-3$ ) and 1.27 bare stents (range, 1-3) were used per patient. The technical success rate was $95.3 \%$ (range, $84 \%-100 \%$ ), with a median operative duration of 141 minutes (range, 40-397 minutes). Supra-aortic branch revascularization was performed in $23.1 \%$ of the patients (25/108). Adjunct endovascular procedures were required in 32 patients $(29.6 \%)$. One patient $(0.9 \%)$ underwent conversion to open surgery because a bare metal strut became lodged in the distal aorta.

\section{Perioperative Outcomes (Table 6)}

Perioperative outcomes were those occurring within the first 30 postoperative days. The overall 30-day mortality was $2.7 \%(3 / 108)$. The early morbidity rate was $51.8 \%$ (range, $0 \%-65 \%$ ). Acute renal failure was the most common early complication $(14.8 \%, 16 / 108)$, with 6 patients in this group requiring dialysis. In studies that reported endoleaks according to subtype, the global incidence of endoleak was $12 \%(13 / 108)$; type I incidence was $5.5 \%(6 / 108)$ and type II was $6.4 \%$ (7/108). The incidence of early

TABLE 1. Case selection

Indication

\begin{tabular}{|c|c|c|c|c|c|c|c|c|c|}
\hline & \multirow[b]{2}{*}{ Study period } & \multirow[b]{2}{*}{ Study type } & \multirow[b]{2}{*}{$\mathbf{N}$} & \multirow[b]{2}{*}{$\operatorname{Age}^{*}(\mathbf{y})$} & \multirow[b]{2}{*}{ Male } & & & & \\
\hline & & & & & & Type A & Type B & Acute & Chronic \\
\hline Nienaber et $\mathrm{al}^{6}$ & - & Retrospective cohort & 12 & $58.7 \pm 10$ & $83 \%$ & $16.6 \%$ & $83.4 \%$ & $0 \%$ & $100 \%$ \\
\hline Hofferberth et $\mathrm{al}^{4}$ & $2003-2010$ & Retrospective cohort & 31 & $57.8 \pm 12.5$ & $71 \%$ & $41.9 \%$ & $58.1 \%$ & $81 \%$ & $19 \%$ \\
\hline Lombardi et $\mathrm{al}^{3}$ & $2007-2009$ & Prospective cohort & 40 & $58 \pm 11$ & $70 \%$ & $0 \%$ & $100 \%$ & $60 \%$ & $40 \%$ \\
\hline Melissano et $\mathrm{al}^{5}$ & $2005-2011$ & Retrospective cohort & 25 & $56 \pm 12$ & $88 \%$ & $0 \%$ & $100 \%$ & $20 \%$ & $80 \%$ \\
\hline
\end{tabular}

All data are percentages of patients except as marked. *Mean \pm SD. 
TABLE 2. Case selection: Patient comorbidities

\begin{tabular}{|c|c|c|c|c|c|c|c|c|c|c|c|}
\hline & \multirow[b]{2}{*}{ HTA } & \multirow[b]{2}{*}{ Diabetes } & \multirow[b]{2}{*}{ Smoking } & \multirow[b]{2}{*}{ Hyperlipidemia } & \multirow[b]{2}{*}{$\begin{array}{l}\text { Cardiac } \\
\text { disease }\end{array}$} & \multirow{2}{*}{$\begin{array}{c}\text { Chronic } \\
\text { obstructive } \\
\text { pulmonary } \\
\text { disease }\end{array}$} & \multirow[b]{2}{*}{$\begin{array}{l}\text { Renal } \\
\text { failure }\end{array}$} & \multicolumn{4}{|c|}{ ASA class } \\
\hline & & & & & & & & I & II & III & IV \\
\hline Nienaber et $\mathrm{al}^{6}$ & $100 \%$ & - & - & $16.6 \%$ & $16.6 \%$ & - & $50 \%$ & $0 \%$ & $0 \%$ & $91.6 \%$ & $8.4 \%$ \\
\hline Hofferberth et $\mathrm{al}^{4}$ & $74.1 \%$ & $9.6 \%$ & $29 \%$ & $22.6 \%$ & $16.1 \%$ & - & - & - & - & - & - \\
\hline Lombardi et $\mathrm{al}^{3}$ & $92.5 \%$ & $7.5 \%$ & $58.3 \%$ & $7.5 \%$ & $10.4 \%$ & $2.6 \%$ & $5 \%$ & - & - & - & - \\
\hline Melissano et $\mathrm{al}^{5}$ & $92 \%$ & $12 \%$ & $52 \%$ & $32 \%$ & $8 \%$ & $0 \%$ & $15 \%$ & $0 \%$ & $32 \%$ & $52 \%$ & $16 \%$ \\
\hline
\end{tabular}

All data are percentages of patients. ASA, American Society of Anesthesiologists; HTA, hypertension.

retrograde dissection was $1.8 \%(2 / 108)$, and periprocedural aortic rupture occurred in $1.8 \%(2 / 108)$. The incidence of neurologic complications was $5.4 \%$ (6/108); of these complications, equal numbers were stroke and paraplegia or paraparesis. The early reintervention rate was $4.6 \%$, and reintervention was required for renal artery occlusion, bowel ischemia, type II endoleak, and bare-stent misdeployment.

\section{Midterm Outcomes (Table 7)}

Midterm outcomes were defined as those occurring after 30 days. The all-cause mortality was 3.8\% (4/105). There were 2 cases of delayed retrograde type A dissection $(1.9 \%)$ and 1 case of aortobronchial fistula $(0.9 \%)$. The most common delayed complication was stent-graft migration $(5 / 105,4.7 \%)$. The incidence of type I endoleak was $3.8 \%(4 / 105)$. No type II endoleaks were reported. Delayed aortic rupture was reported in $1.9 \%(2 / 105)$. Reintervention was necessary in $8.5 \%$ of patients $(4 \%-13.3 \%)$ for complications such as retrograde type A dissection, type I endoleak, stent-graft migration, and aortobronchial fistula (Table 8).

\section{Severe Morbidity Rate}

Severe morbidity was defined as mortality related to aortic repair or any of the following nonfatal adverse events occurring within the postoperative hospital period: central nervous system complication (stroke or spinal cord ischemia with permanent deficit), type I endoleak, retrograde type I dissection, acute renal failure (attested by the need to initiate hemodialysis for the first time), cardiac failure, pulmonary distress syndrome or severe lung infection, bowel ischemia, aortobronchial fistula, and unplanned return to surgery. The overall severe morbidity rate was $33.3 \%(36 / 108)$. The perioperative severe morbidity rate was $17.6 \%(19 / 108)$. The midterm severe morbidity rate was $16.1 \%(17 / 105)$.

\section{Device Performance}

The rate of device failure was $9.2 \%$ (10/108). Component separation or device migration necessitating secondary interventions was reported in 5 patients. One case of focally ruptured Zenith dissection stent was reported, and 4 cases of a stent body misalignment of Cook Zenith dissection stent were reported.

\section{Aortic Remodeling (Table 9)}

Rates of complete false-lumen thrombosis ranged from $31.2 \%$ to $75 \%$ at the thoracic level and from $3.1 \%$ to $25.9 \%$ at the abdominal level. These data were not always complete, and the total number of patients for whom results were available was low. Studies reporting midterm followup of the true lumen demonstrated high rates of false-lumen regression and of true-lumen expansion (Table 9). Nienaber and colleagues ${ }^{6}$ reported an increase in the true-lumen size and a concomitant decrease in the false-lumen size along the dissected aorta at 12 months, with a completely thrombosed thoracic false lumen observed in $75 \%$ of the patients. The fate of the false lumen at the abdominal aorta level was not reported.

Hofferberth and coworkers ${ }^{4}$ reported increased truelumen perfusion and diameter after a mean follow-up of 57.3 months, although perfusion of the abdominal or

TABLE 3. Case selection: Indication for aortic repair

\begin{tabular}{lcccrc}
\hline & $\begin{array}{c}\text { Branch vessel obstruction } \\
\text { or compromise, or correction } \\
\text { of true-lumen collapse }\end{array}$ & $\begin{array}{c}\text { Periaortic effusion } \\
\text { or hematoma }\end{array}$ & $\begin{array}{c}\text { Resistant } \\
\text { hypertension }\end{array}$ & $\begin{array}{c}\text { Persistent pain } \\
\text { or symptoms }\end{array}$ & $\begin{array}{r}\text { Transaortic growth 5 mm } \\
\text { within 3 mo (or transaortic } \\
\text { diameter 40 mm) }\end{array}$ \\
\hline Nienaber et al $^{6}$ & $100 \%$ & $0 \%$ & $0 \%$ & $0 \%$ & $0 \%$ \\
Hofferberth et al $^{4}$ & $100 \%$ & $0 \%$ & $0 \%$ & $0 \%$ & $0 \%$ \\
Lombardi et al $^{3}$ & $67.5 \%$ & $20 \%$ & $65 \%$ & $77.5 \%$ & $52.5 \%$ \\
Melissano et al $^{5}$ & $24 \%$ & $8 \%$ & $68 \%$ & $20 \%$ & $56 \%$ \\
\hline
\end{tabular}

All data are percentages of patients. 
TABLE 4. Technical aspect

\begin{tabular}{|c|c|c|c|c|c|c|}
\hline & Graft types & $\begin{array}{c}\text { SGs per } \\
\text { patient }\end{array}$ & $\begin{array}{l}\text { Bare stents } \\
\text { per patient }\end{array}$ & Adjunct procedures & $\begin{array}{c}\text { Procedure time } \\
(\text { min, mean } \pm \text { SD })\end{array}$ & $\begin{array}{c}\text { Time from dissection } \\
\text { to intervention } \\
\text { (d, median and range) }\end{array}$ \\
\hline Nienaber et $\mathrm{al}^{6}$ & $\begin{array}{l}\text { SG: Talent }(66.6 \%) \text {, Excluder } \\
\quad(16.6 \%), \text { Valiant }(8.3 \%) \text {, } \\
\text { Zenith }(8.3 \%) \text {; bare stent: } \\
\text { Sinus }(41.6 \%), \text { Fortress } \\
(50 \%), \mathrm{Z} \text { stent }(8.4 \%)\end{array}$ & $1.08(1-2)$ & $1.08(1-2)$ & $0 \%(0 / 12)$ & $70 \pm 15$ & - \\
\hline Hofferberth et al ${ }^{4}$ & Zenith Cook dissection & $2.9(1-5)$ & & $\begin{array}{l}\text { 61.2\% (19/31); SG }(6 / 31) \text { : } \\
\text { Iliac, renal, superior } \\
\text { mesenteric arteries; } \\
\text { ascending aorta open repair } \\
(13 / 31)\end{array}$ & - & $10.4(1-1095)$ \\
\hline Lombardi et $\mathrm{al}^{3}$ & Zenith Cook dissection & $1.27(1-3)$ & $1.37(0-3)$ & $\begin{array}{l}\text { 37.5\% }(15 / 40) \text {; bare stent } \\
(9 / 40) \text { : Iliac, renal, superior } \\
\text { mesenteric arteries; } \\
\text { carotid-subclavian bypass } \\
(3 / 40) ; \text { carotid-carotid } \\
\text { bypass }(3 / 40)\end{array}$ & $163(40-397)$ & $20(0-78)$ \\
\hline Melissano et $\mathrm{al}^{5}$ & Zenith Cook dissection & $1.32(1-3)$ & $1.28(1-2)$ & $\begin{array}{l}96 \%(24 / 25) \text {; bare stent: Iliac, } \\
\text { renal, superior mesenteric } \\
\text { arteries }(4 / 25) ; \text { humeral } \\
\text { thrombectomy }(1 / 25) ; \\
\text { carotid-subclavian bypass } \\
(2 / 25) \text {; carotid-carotid } \\
\text { bypass }(17 / 25)\end{array}$ & - & - \\
\hline
\end{tabular}

$S G$, Stent-graft; $S D$, standard deviation.

thoracic aortic false lumen was still observed in $74 \%$ of the patients.

Melissano and colleagues ${ }^{5}$ noted a significant increase $(98 \%)$ in true-lumen volumes at both the thoracic $(115 \%)$ and abdominal segments $(63 \%)$ at a mean follow-up of 57.3 months. At midterm follow-up ( 1 and 2 years), the overall aortic volume tended to decrease to preoperative values. The rate of false-lumen thrombosis was not reported. The abdominal segment, after initial true-lumen expansion, failed to remodel with stable true-lumen volume and had a tendency toward enlargement of the overall abdominal aortic volume as a result of abdominal falselumen expansion.
Lombardi and colleagues ${ }^{3}$ reported an increase in truelumen size and a concomitant decrease in the false-lumen size in the dissected aorta at 12 months. A completely thrombosed thoracic false lumen was observed in $31 \%$ of their patients. Perfusion of the false lumen in thoracic and abdominal aortic segments was still present in $68.8 \%$ and $96.8 \%$ of their patients, respectively.

\section{DISCUSSION}

One of the drawbacks of stent grafting for complicated thoracic aortic dissection is that the thrombosis of the false lumen is frequently not complete, despite thrombosing the false lumen adjacent to the stent-graft during the procedure,

TABLE 5. Technical success and mortality

\begin{tabular}{|c|c|c|c|c|c|c|c|c|}
\hline & \multirow{2}{*}{$\begin{array}{c}\text { Mean } \\
\text { follow-up } \\
\text { (mo) }\end{array}$} & \multirow[b]{2}{*}{$\begin{array}{c}\text { Technical } \\
\text { success rate }\end{array}$} & \multirow[b]{2}{*}{ 1-y survival } & \multirow{2}{*}{$\begin{array}{c}\text { Overall } \\
\text { aortic-related } \\
\text { mortality } \\
\end{array}$} & \multicolumn{2}{|c|}{ 30-d aortic related mortality } & \multicolumn{2}{|c|}{$>$ 30-d aortic-related mortality } \\
\hline & & & & & Rate & Etiology & Rate & Etiology \\
\hline Nienaber et $\mathrm{al}^{6}$ & - & $100 \%$ & $91.6 \%$ & $8.3 \%(1 / 12)$ & $0 \%(0 / 12)$ & & $8.3 \%(1 / 12)$ & $\begin{array}{l}\text { Aortic rupture } \\
\text { in mo } 11\end{array}$ \\
\hline Hofferberth et $\mathrm{al}^{4}$ & 57.3 & $97 \%$ & $93.7 \%$ & $6.4 \%(2 / 31)$ & $3.2 \%(1 / 31)$ & $\begin{array}{l}\text { Stent-graft misdeployment: } \\
\text { surgical conversion }\end{array}$ & $3.3 \%(1 / 30)$ & \\
\hline Lombardi et $\mathrm{al}^{3}$ & - & $100 \%$ & $90 \%$ & $7.9 \%(3 / 38)$ & $5 \%(2 / 40)$ & $\begin{array}{l}\text { Aortic rupture on d 11; } \\
\quad \text { sudden death on day } 29\end{array}$ & $5 \%(2 / 38)$ & $\begin{array}{l}\text { Aortic rupture } \\
\quad \text { on d } 81\end{array}$ \\
\hline Melissano et $\mathrm{al}^{5}$ & $38 \pm 17$ & $84 \%$ & $100 \%$ & $0 \%(0 / 25)$ & $0 \%(0 / 25)$ & & $0 \%(0 / 25)$ & \\
\hline
\end{tabular}

Data represent percentages of patients except as noted. 
TABLE 6. Morbidity within 30 days

\begin{tabular}{ccccccccccc}
\hline & $\begin{array}{c}\text { Mean } \\
\text { follow-up } \\
(\mathbf{m o})\end{array}$ & $\begin{array}{c}\text { Overall } \\
\text { morbidity }\end{array}$ & $\begin{array}{c}\text { Aortic } \\
\text { rupture }\end{array}$ & $\begin{array}{c}\text { Type I } \\
\text { endoleak }\end{array}$ & $\begin{array}{c}\text { Type II } \\
\text { endoleak }\end{array}$ & Stroke & $\begin{array}{c}\text { Paraparesis } \\
\text { or paraplegia }\end{array}$ & $\begin{array}{c}\text { Retrograde } \\
\text { dissection }\end{array}$ & $\begin{array}{c}\text { Cardiopulmonary } \\
\text { Renal } \\
\text { failure }\end{array}$ & $\begin{array}{c}\text { Bowel } \\
\text { ischemia }\end{array}$ \\
\hline $\begin{array}{c}\text { Nienaber } \\
\text { et al }\end{array}$ & - & $0 \%(0 / 12)$ & $0 \%$ & $0 \%$ & - & $0 \%$ & $0 \%$ & $0 \%$ & $0 \%$ & $0 \%$ \\
$\begin{array}{c}\text { Hofferberth } \\
\text { et al }\end{array}$ \\
$\begin{array}{c}\text { Lombardi } \\
\text { et al }\end{array}$
\end{tabular}

Data represent percentages of patients except as noted.

as a consequence of retrograde flow through the residual reentry tear or intimal fenestrations related to branch vessels.

This incomplete thrombosis exposes patients to increased risk of late aneurysmal degeneration and therefore aortic rupture. It has been reported by Tsai and colleagues $^{2}$ that the natural course of false-lumen partial thrombosis in type B aortic dissection has a worse prognosis than that of a completely patent false lumen. Complete exclusion of the false lumen should therefore clearly be the aim wherever possible. ${ }^{2}$ To promote true-lumen expansion and false-lumen thrombosis, some authors have proposed the use of bare metal stents in the distal thoracoabdominal aorta. The PETTICOAT, (or Provisional ExTension To Induce COmplete ATtachment) technique, was first reported in 2005 by Mossop and colleagues, ${ }^{7}$ and in 2006 a series of 12 cases was reported. ${ }^{6}$ This technique eliminates the entry tear and increases the true-lumen diameter in the distal aorta through a combination of stent grafting and bare metal stenting of the visceral and infrarenal segments.

To compare the results of proximal stent grafting with distal bare stenting against stent-graft placement without distal bare stenting for management of aortic dissection, a review of series reporting results for the latter technique in the management of complicated acute and chronic aortic dissection was performed (Tables 10-12). ${ }^{8-27}$ The technical success rates reported for proximal stent grafting with distal bare stenting for management of aortic dissection were high $(95.3 \%)$ and were similar to reported success rates of established endovascular techniques that used stent-grafts without distal bare stenting. The mean 30-day mortality after combined proximal stent grafting with distal bare stenting for acute and chronic aortic dissection in this study was $2.7 \%$. This mortality is similar to rates recently reported by several authors describing results of TEVAR for acute and chronic dissection. Of especial note, however, was the rate of severe morbidity. The pooled rate of severe morbidity in this series was $33.3 \%$ (36/108). A metaanalysis describing the results of TEVAR for acute and chronic dissection reported a major complication rate of $11.1 \% \pm 1.4 \%{ }^{16}$ The most critical complications were related to retrograde extension of the dissection into the ascending aorta, neurologic complications, and aortic rupture. This more extensive approach was associated with slightly higher rates of dissection into the ascending aorta (3.7 vs $1.8 \%$ ), neurologic complications (5.5 vs $3.1 \%$ ), and aortic rupture (3.7 vs $2.5 \%$ ); however, patients treated in this study represent a difficult patient subgroup, with $63.8 \%$ of the patients being seen with malperfusion or impending rupture. Eggebrecht and associates ${ }^{8}$ reported

TABLE 7. Morbidity after 30 days

\begin{tabular}{|c|c|c|c|c|c|c|c|c|c|c|}
\hline & \multirow{2}{*}{$\begin{array}{c}\text { Mean } \\
\text { follow-up } \\
(\mathbf{m o}) \\
\end{array}$} & \multirow[b]{2}{*}{$\begin{array}{c}\text { Overall } \\
\text { morbidity }\end{array}$} & \multicolumn{8}{|c|}{$>$ 30-d morbidity } \\
\hline & & & $\begin{array}{c}\text { Aortic } \\
\text { rupture }\end{array}$ & $\begin{array}{c}\text { Type I } \\
\text { endoleak }\end{array}$ & $\begin{array}{r}\text { Type II } \\
\text { endoleak }\end{array}$ & $\begin{array}{c}\text { Stent-graft } \\
\text { migration }\end{array}$ & $\begin{array}{c}\text { Retrograde } \\
\text { dissection }\end{array}$ & Cardiopulmonary & $\begin{array}{l}\text { Renal } \\
\text { failure }\end{array}$ & $\begin{array}{c}\text { Aortobronchial } \\
\text { fistula }\end{array}$ \\
\hline $\begin{array}{c}\text { Nienaber } \\
\text { et }^{2} l^{6}\end{array}$ & - & $16.6 \%(2 / 12)$ & $8.3 \%(1 / 12)$ & $8.3 \%(1 / 12)$ & - & $0 \%$ & $0 \%$ & $0 \%$ & $0 \%$ & $0 \%$ \\
\hline 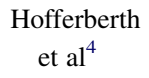 & 57.3 & $16.6 \%(5 / 30)$ & $3.3 \%(1 / 30)$ & $3.3 \%(1 / 30)$ & - & $3.3 \%(1 / 30)$ & $3.3 \%(1 / 30)$ & $0 \%$ & $0 \%$ & $3.3 \%(1 / 30)$ \\
\hline $\begin{array}{l}\text { Lombardi } \\
\text { et } \mathrm{al}^{3}\end{array}$ & - & $18.4 \%(7 / 38)$ & $2.6 \%(1 / 38)$ & $2.6 \%(1 / 38)$ & $0 \%$ & $5.2 \%(2 / 38)$ & $2.6 \%(1 / 38)$ & $2.6 \%(1 / 38)$ & $2.6 \%(1 / 38)$ & $0 \%$ \\
\hline $\begin{array}{c}\text { Melissano } \\
\text { et }^{5}{ }^{5}\end{array}$ & $38 \pm 17$ & $12 \%(3 / 25)$ & $0 \%$ & $4 \%(1 / 25)$ & $0 \%$ & $8 \%(2 / 25)$ & $0 \%$ & $0 \%$ & $0 \%$ & $0 \%$ \\
\hline
\end{tabular}

Data represent percentages of patients except as noted. 
TABLE 8. Secondary interventions

\begin{tabular}{|c|c|c|c|c|c|}
\hline & \multirow{2}{*}{$\begin{array}{c}\text { Mean } \\
\text { follow-up (mo) }\end{array}$} & \multicolumn{2}{|r|}{$<\mathbf{3 0}$ d } & \multicolumn{2}{|r|}{$>\mathbf{3 0 ~ d}$} \\
\hline & & Rate & Cause & Rate & Cause \\
\hline Nienaber et $\mathrm{al}^{6}$ & - & $0 \%(0 / 12)$ & & $8.3 \%(1 / 12)$ & Type I endoleak \\
\hline Hofferberth et al ${ }^{4}$ & 57.3 & $3.2 \%(1 / 31)$ & Bare stent misdeployment & $13.3 \%(4 / 30)$ & $\begin{array}{l}\text { Retrograde type A dissection, } \\
\text { proximal stent-graft migration, } \\
\text { aortobronchial fistula, type I } \\
\text { endoleak }\end{array}$ \\
\hline Lombardi et $\mathrm{al}^{3}$ & - & $7.5 \%(3 / 40)$ & $\begin{array}{l}\text { Liver and gall bladder ischemia, } \\
\text { renal artery stenting, renal artery } \\
\text { stenting }\end{array}$ & $7.9 \%(3 / 38)$ & $\begin{array}{l}\text { Retrograde type A dissection, } \\
\text { retrograde type A dissection and } \\
\text { stent-graft migration, type I } \\
\text { endoleak }\end{array}$ \\
\hline Melissano et $\mathrm{al}^{5}$ & $38 \pm 17$ & $4 \%(1 / 25)$ & Type II endoleak & $4 \%(1 / 25)$ & Stent-graft migration \\
\hline
\end{tabular}

the most favorable outcomes. Among 12 patients with a malperfusion syndrome, the overall severe morbidity was $16.6 \%$ : 1 patient died of an aortic rupture, and another received an additional stent-graft for a type I endoleak. This favorable result may be explained by the fact that this group advocated a staged approach to the procedure, allowing recovery from the acute insult of dissection and the initial procedure before evaluation of the need for extension of the graft with the bare metal components. Persistence of a distal malperfusion syndrome after proximal covered endograft placement is uncommon. Nienaber and colleagues ${ }^{6}$ only reported this issue in 12 patients among a cohort of 100 patients $(12 \%)$. This suggests that distal bare stenting could be planned only after evaluation after primary entry tear closure, rather than performed as a single-stage extensive repair of the thoracoabdominal aorta.

Achievement of a complete false-lumen thrombosis is challenging, and pursuing this goal compounds the risks of multiple procedures, cumulative radiation dose, and contrast exposure. By treating the entire thoracoabdominal aorta, combined proximal stent grafting with distal bare stenting, should limit the number of adjunct procedures required. The reintervention rate was $16.6 \%$ for severe complications, such as renal arterial occlusion, type I endoleak, retrograde dissection, aortic rupture, and aortobronchial fistula.

Hofferberth and coworkers ${ }^{4}$ reported that adjunct bare metal stenting did not compromise branch vessel perfusion. This statement needs to be qualified. Adjunct intraoperative endovascular procedures to maintain patency of visceral or iliac arteries were required for 19 arteries. When compared with results of a recent study of TEVAR without distal bare stenting for management of complicated aortic dissection, ${ }^{16}$ the rate of adjunct endovascular procedures was significantly lower ( $1 \%$ vs $17.6 \%)$ than after bare metal stent deployment in the distal thoracoabdominal aorta.

Device concerns have also been reported. Bertoglio and coworkers ${ }^{28}$ reported the risk of stent misalignment, probably resulting from excessive manipulation of the delivery system or during catheter manipulation during adjunct or secondary procedures. Melissano and colleagues ${ }^{5}$ reported 1 focally ruptured bare stent. Lombardi and colleagues ${ }^{3}$ reported component separation or device migration necessitating secondary interventions in 2 patients. Hofferberth and coworkers ${ }^{4}$ reported 1 case in which the bare stent became dislodged in the distal aorta, necessitating

TABLE 9. Aortic remodeling

\begin{tabular}{|c|c|c|c|c|c|}
\hline & \multirow[b]{2}{*}{ Change in TL-FL ratio } & \multicolumn{2}{|c|}{ Thoracic aorta FL thrombosis } & \multicolumn{2}{|c|}{ Abdominal aorta FL thrombosis } \\
\hline & & Complete & Partial & Complete & Partial \\
\hline Nienaber et $\mathrm{al}^{6}$ & $\begin{array}{l}\text { At } 1 \text { y: before stenting } \mathrm{TL}: \mathrm{FL}=4 / 25=0.16 \text {, } \\
\text { after stenting } \mathrm{TL}: \mathrm{FL}=23 / 11=2.1\end{array}$ & $75 \%(9 / 12)$ & $8.3 \%(1 / 12)$ & - & - \\
\hline Hofferberth et $\mathrm{al}^{4}$ & $\begin{array}{l}\text { At } 1 \mathrm{y} \text { : before stenting TL expansion/ } \\
\mathrm{FL}=84 / 332=0.25 \text {, after stenting } \\
\text { TL:FL }=216 / 248=0.87\end{array}$ & $66.6 \%(18 / 27)$ & $33.4 \%(9 / 27)$ & $25.9 \%(7 / 27)$ & $70.3 \%(19 / 27)$ \\
\hline 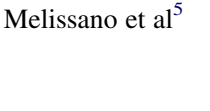 & $\begin{array}{l}\text { At } 2 \text { y: FL reduction }=65 \% \text {; before stenting } \\
\text { TL:FL }=84 / 332=0.25 \text {, after stenting } \\
\quad \text { TL:FL }=216 / 248=0.87\end{array}$ & - & - & - & - \\
\hline Lombardi et $\mathrm{al}^{3}$ & $\begin{array}{l}\text { At } 1 \mathrm{y} \text { : TL increased }(P<.05) \text {, FL decreased } \\
\quad(P<.05)\end{array}$ & $31.2 \%(10 / 32)$ & $68.8 \%(22 / 32)$ & $3.1 \%(1 / 32)$ & $81.3 \%(26 / 32)$ \\
\hline
\end{tabular}

Data represent percentages of patients except as noted. $F L$, False lumen; $T L$, true lumen. 
TABLE 10. Endovascular stent-graft repair without distal bare stenting for management of acute and chronic complicated type B aortic dissection

\begin{tabular}{|c|c|c|c|c|c|c|c|c|c|c|c|}
\hline First author & Year & $\mathbf{n}$ & Acute (n) & $\begin{array}{c}\text { Technical } \\
\text { success }\end{array}$ & $\begin{array}{c}\text { Retrograde } \\
\text { dissection }\end{array}$ & Stroke & Paraplegia & Renal failure & $\begin{array}{c}\text { Adjunct } \\
\text { distal } \\
\text { reperfusion }\end{array}$ & $\begin{array}{l}\text { Aortic } \\
\text { rupture }\end{array}$ & $\begin{array}{c}\text { 30-d } \\
\text { mortality }\end{array}$ \\
\hline $\begin{array}{l}\text { Eggebrecht }^{8} \\
\quad \text { (meta-analysis) }\end{array}$ & 2006 & 609 & 248 & $98 \%$ & $1.9 \%$ & $1.9 \%$ & $0.8 \%$ & NA & NA & $2.3 \%$ & $5.3 \%$ \\
\hline Dialetto 9 & 2005 & 56 & 14 & $100 \%$ & $4 \%$ & $0 \%$ & $0 \%$ & NA & $0 \%$ & $1.7 \%$ & $10.7 \%$ \\
\hline Nathanson $^{10}$ & 2005 & 40 & 23 & $95 \%$ & NA & $2.5 \%$ & $2.5 \%$ & $13 \%$ & $0 \%$ & $0 \%$ & $2.5 \%$ \\
\hline Sayer ${ }^{11}$ & 2008 & 78 & 38 & $100 \%$ & $1.2 \%$ & $0 \%$ & $2.5 \%$ & NA & $0 \%$ & $3.8 \%$ & $5.1 \%$ \\
\hline Böckler ${ }^{12}$ & 2009 & 54 & 24 & $93 \%$ & $3.7 \%$ & $0 \%$ & $0 \%$ & NA & $0 \%$ & $0 \%$ & $11.1 \%$ \\
\hline Kische $^{13}$ & 2009 & 180 & 37 & $98.3 \%$ & $1.8 \%$ & $3.9 \%$ & $2.8 \%$ & NA & $2.7 \%$ & $4.2 \%$ & $5 \%$ \\
\hline Younes $^{14}$ & 2010 & 23 & 11 & $100 \%$ & $0 \%$ & $5.5 \%$ & $5.5 \%$ & $0 \%$ & $0 \%$ & $0 \%$ & $5.5 \%$ \\
\hline Parsa $^{15}$ & 2010 & 55 & 22 & $100 \%$ & $0 \%$ & $0 \%$ & $2 \%$ & $1.8 \%$ & $0 \%$ & $0 \%$ & $2 \%$ \\
\hline Yang $^{16}$ & 2012 & 61 & 33 & $100 \%$ & $1.6 \%$ & $1.6 \%$ & $1.6 \%$ & $1.6 \%$ & $1.6 \%$ & $6.5 \%$ & $6.5 \%$ \\
\hline Overall & & 1156 & $450(38.9 \%)$ & $98.3 \%$ & $1.8 \%$ & $1.9 \%$ & $1.2 \%$ & NA & $1 \%$ & $2.5 \%$ & $5.5 \%$ \\
\hline
\end{tabular}

Data represent percentages of patients except as noted. NA, Not available.

conversion to open surgery and leading to the death of the patient.

The combination of proximal stent grafting with distal bare stenting for management of aortic dissection clearly improved true-lumen perfusion and diameter; however, it apparently failed to suppress false-lumen patency completely. At 1-year, false-lumen patency was still present in $29.6 \%$ of the patients at the thoracic level and in $86.5 \%$ of the patients at the abdominal level. Data on patients for whom complete imaging was available beyond this period were limited. Yang and colleagues ${ }^{16}$ studied aortic remodeling after TEVAR for acute and chronic dissection, and they reported a comparable rate of false-lumen patency of $19.4 \%$ at the thoracic level at 1 year.

This review has several limitations. Although it is the only review to date on combined proximal stent grafting with distal bare stenting for management of aortic dissection, the pooled results are weakened by the lack of standardization in reporting patients' specific data and end points. In addition, the data are insufficient for separate analyses of outcomes for acute or chronic dissections. Furthermore, we specifically focused the review on clinical outcome. Finally, some studies with small sample sizes were included, whereas a larger number of patients is needed for better identification of statistically significant differences.

\section{CONCLUSIONS}

In this analysis, the combination of proximal stent grafting with distal bare stenting for the management of aortic dissection clearly improved true-lumen perfusion and diameter; however, it failed to suppress false-lumen patency completely and carried nontrivial risks of severe morbidity. Distal bare stenting could be proposed as a second stage to treat cases of persistent distal malperfusion syndrome after careful evaluation of the immediate results of primary entry tear closure, rather than as part of an extensive single-stage repair of the thoracoabdominal aorta. Nevertheless, no reliable long-term data exist to assess the durability of combined proximal stent grafting with distal bare stenting for the management of aortic dissection, and contemporary conclusions spring mainly from relatively small case series or retrospective studies. Furthermore, results of management of acute and chronic dissection should be reported separately to allow a more accurate analysis. Prospective trials of combined proximal stent grafting with distal bare stenting versus stent grafting

TABLE 11. Endovascular stent-graft repair without distal bare stenting for management of acute complicated type B aortic dissection

\begin{tabular}{|c|c|c|c|c|c|c|c|c|c|c|}
\hline & Year & $\mathbf{N}$ & $\begin{array}{c}\text { Technical } \\
\text { success }\end{array}$ & $\begin{array}{c}\text { Retrograde } \\
\text { dissection }\end{array}$ & Stroke & Paraplegia & $\begin{array}{l}\text { Renal } \\
\text { failure }\end{array}$ & $\begin{array}{c}\text { Adjunct distal } \\
\text { reperfusion }\end{array}$ & $\begin{array}{c}\text { Aortic } \\
\text { rupture }\end{array}$ & $\begin{array}{c}\text { 30-d } \\
\text { mortality }\end{array}$ \\
\hline Conrad $^{17}$ & 2009 & 33 & 100 & 9 & 3 & 12 & 0 & 0 & 6 & 12 \\
\hline Khoynezhad $^{18}$ & 2009 & 28 & 90 & 3.5 & 3.3 & 0 & 10 & 3.5 & 0 & 11 \\
\hline $\mathrm{Shu}^{19}$ & 2010 & 45 & 100 & 0 & 0 & 0 & 4.4 & 0 & 0 & 4.4 \\
\hline White ${ }^{20}$ & 2011 & 85 & 100 & 0 & 9.4 & 9.4 & 9.4 & 4.7 & 14 & 10.6 \\
\hline $\operatorname{Qin}^{21}$ & 2012 & 124 & 100 & 24 & 0.8 & 0.8 & NA & 13.7 & 0 & 0 \\
\hline Ehrlich $^{22}$ & 2013 & 29 & 100 & 3.4 & 6.8 & 0 & 0 & 20 & 6.8 & 17 \\
\hline Overall & 28 & 450 & 450 & 450 & 450 & 450 & 450 & 450 & 450 & 450 \\
\hline
\end{tabular}

Data represent percentages of patients except as noted. $N A$, Not available. 
TABLE 12. Endovascular stent-graft repair without distal bare stenting for management of chronic complicated type B aortic dissection

\begin{tabular}{|c|c|c|c|c|c|c|c|c|c|c|}
\hline & Year & $\mathbf{N}$ & $\begin{array}{c}\text { Technical } \\
\text { success }\end{array}$ & $\begin{array}{c}\text { Retrograde } \\
\text { dissection }\end{array}$ & Stroke & Paraplegia & $\begin{array}{l}\text { Renal } \\
\text { failure }\end{array}$ & $\begin{array}{c}\text { Adjunct } \\
\text { distal reperfusion }\end{array}$ & $\begin{array}{l}\text { Aortic } \\
\text { rupture }\end{array}$ & $\begin{array}{c}\text { 30-d } \\
\text { mortality }\end{array}$ \\
\hline $\mathrm{Kim}^{23}$ & 2009 & 72 & $97.2 \%$ & $0 \%$ & $0 \%$ & $0 \%$ & $1.4 \%$ & $0 \%$ & $0 \%$ & $0 \%$ \\
\hline $\mathrm{Xu}^{24}$ & 2010 & 84 & $91.7 \%$ & $0 \%$ & $0 \%$ & $0 \%$ & $4.8 \%$ & $0 \%$ & $4.8 \%$ & $1.2 \%$ \\
\hline Czerny $^{25}$ & 2010 & 14 & $85.7 \%$ & $0 \%$ & $0 \%$ & $0 \%$ & $0 \%$ & $0 \%$ & $0 \%$ & $0 \%$ \\
\hline $\mathrm{Kang}^{26}$ & 2011 & 76 & $96 \%$ & $3.9 \%$ & $1.3 \%$ & $0 \%$ & $0 \%$ & $0 \%$ & $0 \%$ & $5 \%$ \\
\hline Andacheh $^{27}$ & 2012 & 73 & $99 \%$ & $5.4 \%$ & $1 \%$ & $1 \%$ & $0 \%$ & $0 \%$ & $2.7 \%$ & $14 \%$ \\
\hline Total & & 319 & $95.8 \%$ & $2.1 \%$ & $1.8 \%$ & $0.3 \%$ & $1.5 \%$ & $0 \%$ & $1.8 \%$ & $4.7 \%$ \\
\hline
\end{tabular}

Data represent percentages of patients except as noted.

without distal bare stenting are needed to assess outcomes of this extensive approach.

\section{References}

1. Szeto WY, McGarvey M, Pochettino A, Moser GW, Hoboken A, Cornelius K, et al. Results of a new surgical paradigm: endovascular repair for acute complicated type B aortic dissection. Ann Thorac Surg. 2008;86:87-93; discussion 93-4.

2. Tsai TT, Evangelista A, Nienaber CA, Myrmel T, Meinhardt G, Cooper JV, et al. Partial thrombosis of the false lumen in patients with acute type B aortic dissections. N Engl J Med. 2007;357:349-59.

3. Lombardi JV, Cambria RP, Nienaber CA, Chiesa R, Teebken O, Lee A, et al. Prospective multicenter clinical trial (STABLE) on the endovascular treatment of complicated type B aortic dissection using a composite device design. J Vasc Surg. 2012;55:629-40.e2.

4. Hofferberth SC, Foley PT, Newcomb AE, Yap KK, Yii MY, Nixon IK, et al. Combined proximal endografting with distal bare-metal stenting for management of aortic dissection. Ann Thorac Surg. 2012;93:95-102.

5. Melissano G, Bertoglio L, Rinaldi E, Civilini E, Tshomba Y, Kahlberg A, et al. Volume changes in aortic true and false lumen after the "PETTICOAT" procedure for type B aortic dissection. J Vasc Surg. 2012;55:641-51.

6. Nienaber CA, Kische S, Zeller T, Rehders TC, Schneider H, Lorenzen B, et al. Provisional extension to induce complete attachment after stent-graft placement in type B aortic dissection: the PETTICOAT concept. J Endovasc Ther. 2006;13: 738-46.

7. Mossop PJ, McLachlan CS, Amukotuwa SA, Nixon IK. Staged endovascular treatment for complicated type B aortic dissection. Nat Clin Pract Cardiovasc Med. 2005;2:316-21. quiz 322.

8. Eggebrecht H, Nienaber CA, Neuhäuser M, Baumgart D, Kische S, Schmermund A, et al. Endovascular stent-graft placement in aortic dissection: a meta-analysis. Eur Heart J. 2006;27:489-98.

9. Dialetto G, Covino FE, Scognamiglio G, Manduca S, Della Corte A, Giannolo B, et al. Treatment of type B aortic dissection: endoluminal repair or conventional medical therapy? Eur J Cardiothorac Surg. 2005;27:826-30.

10. Nathanson DR, Rodriguez-Lopez JA, Ramaiah VG, Williams J, Olsen DM, Wheatley GH, et al. Endoluminal stent-graft stabilization for thoracic aortic dissection. J Endovasc Ther. 2005;12:354-9.

11. Sayer D, Bratby M, Brooks M, Loftus I, Morgan R, Thompson M. Aortic morphology following endovascular repair of acute and chronic type B aortic dissection: implications for management. Eur J Vasc Endovasc Surg. 2008;36: 522-9.

12. Böckler D, Hyhlik-Dürr A, Hakimi M, Weber TF, Geisbüsch P. Type B aortic dissections: treating the many to benefit the few? J Endovasc Ther. 2009;16(Suppl 1):80-90.

13. Kische S, Ehrlich MP, Nienaber CA, Rousseau H, Heijmen R, Piquet P, et al. Endovascular treatment of acute and chronic aortic dissection: midterm results from the Talent Thoracic Retrospective Registry. J Thorac Cardiovasc Surg. 2009;138: 115-24.
14. Younes HK, Harris PW, Bismuth J, Charlton-Ouw K, Peden EK, Lumsden AB, et al. Thoracic endovascular aortic repair for type B aortic dissection. Ann Vasc Surg. 2010;24:39-43.

15. Parsa CJ, Schroder JN, Daneshmand MA, McCann RL, Hughes GC. Midterm results for endovascular repair of complicated acute and chronic type B aortic dissection. Ann Thorac Surg. 2010;89:97-102; discussion 102-4.

16. Yang CP, Hsu CP, Chen WY, Chen IM, Weng CF, Chen CK, et al. Aortic remodeling after endovascular repair with stainless steel-based stent graft in acute and chronic type B aortic dissection. J Vasc Surg. 2012;55:1600-10.

17. Conrad MF, Crawford RS, Kwolek CJ, Brewster DC, Brady TJ, Cambria RP. Aortic remodeling after endovascular repair of acute complicated type B aortic dissection. J Vasc Surg. 2009;50:510-7.

18. Khoynezhad A, Donayre CE, Omari BO, Kopchok GE, Walot I, White RA. Midterm results of endovascular treatment of complicated acute type B aortic dissection. J Thorac Cardiovasc Surg. 2009;138:625-31.

19. Shu C, He H, Li QM, Li M, Jiang XH, Luo MY. Endovascular repair of complicated acute type-B aortic dissection with stentgraft: early and mid-term results. Eur J Vasc Endovasc Surg. 2011;42:448-53.

20. White RA, Miller DC, Criado FJ, Dake MD, Diethrich EB, Greenberg RK, et al. Report on the results of thoracic endovascular aortic repair for acute, complicated, type B aortic dissection at 30 days and 1 year from a multidisciplinary subcommittee of the Society for Vascular Surgery Outcomes Committee. J Vasc Surg. 2011;53:1082-90.

21. Qin YL, Deng G, Li TX, Jing RW, Teng GJ. Risk factors of incomplete thrombosis in the false lumen after endovascular treatment of extensive acute type B aortic dissection. J Vasc Surg. 2012;56:1232-8.

22. Ehrlich MP, Rousseau H, Heijmen R, Piquet P, Beregi JP, Nienaber CA, et al. Midterm results after endovascular treatment of acute, complicated type $B$ aortic dissection: the Talent Thoracic Registry. J Thorac Cardiovasc Surg. 2013;145:159-65.

23. Kim U, Hong SJ, Kim J, Kim JS, Ko YG, Choi D, et al. Intermediate to long-term outcomes of endoluminal stent-graft repair in patients with chronic type B aortic dissection. J Endovasc Ther. 2009;16:42-7.

24. Xu SD, Huang FJ, Yang JF, Li ZZ, Yang S, Du JH, et al. Early and midterm results of thoracic endovascular aortic repair of chronic type B aortic dissection. J Thorac Cardiovasc Surg. 2010;139:1548-53.

25. Czerny M, Roedler S, Fakhimi S, Sodeck G, Funovics M, Dumfarth J, et al. Midterm results of thoracic endovascular aortic repair in patients with aneurysms involving the descending aorta originating from chronic type B dissections. Ann Thorac Surg. 2010;90:90-4.

26. Kang WC, Greenberg RK, Mastracci TM, Eagleton MJ, Hernandez AV, Pujara AC, et al. Endovascular repair of complicated chronic distal aortic dissections: intermediate outcomes and complications. J Thorac Cardiovasc Surg. 2011;142:1074-83.

27. Andacheh ID, Donayre C, Othman F, Walot I, Kopchok G, White R. Patient outcomes and thoracic aortic volume and morphologic changes following thoracic endovascular aortic repair in patients with complicated chronic type B aortic dissection. J Vasc Surg. 2012;56:644-50; discussion 650.

28. Bertoglio L, Melissano G, Civilini E, Chiesa R. Stent misalignment of the Zenith Dissection Endovascular System. J Vasc Surg. 2013;57:515-7. 